\title{
The Effect of Traditional Games, Self-Confidence, and Learning Style on Mathematical Logic Intelligence
}

\author{
Anik Lestariningrum \\ Early Childhood Education Department \\ Universitas Nusantara PGRI Kediri, Indonesia \\ anikl@unpkediri.ac.id
}

\begin{abstract}
Abstrac--The purpose of this research is to know the influence of traditional game, self-confidence and learning style to logical mathematical intelligence of children aged 5-6 years Kindergarten in Grogol District, Kediri Regency East Java Province. The method used in this research is experiment with 2 x $2 \times 2$ factorial design. Data analysis used Anova three factors. Sampling was done by multi stage random sampling technique with a sample of 96 children, and randomized for traditional gamelan treatment. The results showed that; (1) traditional game conglak gives a better effect on mathematical logical intelligence, (2) higher self-esteem have better impact on mathematical logical intelligence, (3) visual learning style have better impact on logical mathematical intelligence, (4) there is influence of game interaction Traditional and confident in mathematical logical intelligence, (5) there is an interaction effect between traditional games and learning styles on logical mathematical intelligence (6) there is an interaction effect between self-confidence and learning style to logical mathematical intelligence, (7) there is interaction effect between game Traditional, self-confident and learning style to the logical intelligence of mathematic children aged 5-6 years. The conclusion that can be drawn from this research if you want to improve mathematical logical intelligence through traditional game should pay attention to level of confidence and learning style owned by child.
\end{abstract}

Keywords--traditional games; self-confidence; learning style, logical mathematical intelligence

\section{INTRODUCTION}

Early childhood education is a fundamental education and cannot be separated from the playing world as a part of the child's life that must be met. Improper handling of children will affect subsequent developments. Various types of play activities have been optimized in early childhood learning is also a traditional game that is a nation's cultural heritage that must be preserved and introduced to children from an early age as the next child heirs of the nation.

Traditional games are many different types based on the cultural culture standard that exists in every region. According to Arth and Bush quoted by Danandjaja, (in Sujarno) [1] divides the traditional game into two big groups, the traditional game for play and games to play. The difference is if the game play is fill leisure or recreation, while the game more organized, competitive, must be played more two people, have the criteria of determination and winning, have timwclear rules.

As research conducted by Wang, [2] about how the traditional Javanese dolanan game in Yogjakarta as a child's development in musical ability. When explored in more deeply, traditional Javanese games of singing, games, orchestras, have many functions in developing the cognitive and social abilities of children.

The concept of traditional games that can not be separated from the world of children play will be done better if done with a high confidence. The confidence of a child is also very important when the child is doing activities or activities. Having the confidence to make children more confident to complete the work that has been given to him. As a study by Macllellan, [3] which states that, "In the context of learnercentered learning and curricular reform, self-confidence is invoked as an important construct."

In addition to the importance of self-confidence children understand the learning style of children is also very decisive a child can achieve stages of development according to individual as an effort to position the child as himself. Research that supports the style of learning by Rodica. [4] The committed learning style has several distinctive features; the cognitive capacity of the learners to find new useful knowledge for their intrinsic motivation, curiosity, and inquiry with the complex learning process.

Based on researcher's observation at Kindergarten in Grogol Sub district, Kediri Regency, East Java Province got data of mathematical ability of child is still low. It shows many children who have not mastered the concept of numbers / numbers, sort patterns, classify geometric shapes, the ability to think logically as to know the cause of where the activity is often given the teacher in learning. Understanding the child about the concept of numbers / concepts of numbers, sorting patterns, classifying geometric shapes, the ability to think logically as to know cause and effect is a skill capital needed by children in solving problems of life in the future which is conceptually expressed as mastery of logical mathematical intelligence. This happens due to the lack of implementation 
of learning and understanding of the material done by the teacher.

Based on the above descriptions the authors are interested in researching logical mathematical intelligence through the application of traditional games, confidence and learning styles. It is expected that the results of research will be able to show that the application of traditional games in learning is influenced by self-confidence and learning style can improve the logical intelligence of mathematical children.

\section{THEORETICAL STUDY}

\section{Logical Mathematical Intelligence}

Logical mathematical intelligence is rooted in the theory of multiple intellegences or multiple intelligences. Gardner, [5] proposed a theory called multiple intelligences in his book Frames of Mind. From the theory that said this, there are many ways children learn and children use different intelligence to learn a skill or concept.

Logical mathematically related to the scope of scientific ability. This is the kind of intelligence examined and documented by Piaget, (in Jasmine) [6] that type of intelligence is often characterized as critical thinking and used as part of the scientific method. People with this intelligence love to work with data; collecting and organizing, analyzing and interpreting, summing up then predicting. They see and observe the patterns and interrelationships between data. They like solving mathematical problems and playing strategy games.

The use of math in everyday activities also involves logic. According to Eysenck, (in Suharnan) [7] that logic plays an important role in the main mathematical material. Logic is a formal system for generating inferences; a set of rules that enable a person to reach a valid conclusion about an object or an event.

According to Armstrong, [8] identifying mathematical logical intelligence in a child can also be done with the tendency of the child's interest in something. The process of achieving this ability is also largely accomplished by someone in the field of work concerning various matters in numerical skills, data processing, and quick thinking in solving problem.

To learn or develop mathematical logical intelligence in early childhood should be appropriate development stage, besides the concept of playing in children should not be abandoned as the world of early childhood. Traditional play and games are a legacy for generations as a very important learning tool, traditional play and games are not deliberate elements because they are culturally related and aim for recreational fun. This is in line with the results of the review by Ajila and Olowu [9]; "Children's games often handed down through generations are one of childhood; s most important important tool and socializing mechanisms."

\section{Traditional game}

The diversity of cultures and games in Indonesia is very diverse. The traditional game is inseparable from the cultural culture of Indonesian society. The concept of traditional games contains elements similar to the concept of playing in early childhood.

The development of information technology began to shift the existence of traditional games. As a nation's cultural heritage that needs to be preserved, traditional games should also be introduced to children from an early age. Traditional games in this study use traditional games of congklak and engklek as stimulation intervention development of logical mathematical intelligence. Congklak is a simple game that sharpens the child's reasoning power. Uniquely this game trains the child's trading soul, and the sharpness of thinking to take advantage. In general, congklak boards made of wood or plastic and a kind of shellfish are used as congklak seeds and if not present, sometimes also used grains from plants. The congklak game according to Ja'far, Yani, and Sigit, [10] uses a game board that has 14 holes and 2 large holes located on the left and right ends. Every 7 small holes in the side of the player and a large hole on the right side is considered as the player's owner. This game can only be played by 2 people.

According to Apriani, [11] the game of the aprons (in Javanese) is a traditional jumping game on flat plots drawn on the ground, drawing plaid drawings and then jumping on one foot from the box of the next one. The usual crank game is played by 2 to 5 girls and is performed in the yard. However, before we start this game we have to draw boxes in cement, asphalt or soil, drawing a rectangular vertex 5 then on the right and left again given a rectangle.

\section{Confidence}

Child's confidence is a must-have for the child's interests in interacting with others. Confidence is an attitude that arises from the desire to manifest itself to act and succeed. The issue of the importance of self-confidence is also a study conducted by Flowers and Marston, [12] "the issue of self-confidence is a critical one in education, and more especially in elementary education. The noconfident child is a source of worry to his parents and his teachers."

Self-concept also includes confidence. According to Burns,(in Desmita [13] the concept of self is the relationship between an attitude of belief about ourselves. While Atwater, (in Desmita)[13] defines the concept of self as a dynamic and complex system of beliefs one has about oneself, including the unique attitudes, feelings, perceptions, values and behaviors of the individual.

Confidence is an attitude that arises from the desire to manifest itself to act and succeed. Implanting self-confidence in children is a gradual process. This process cannot be direct at once, but requires small steps. Early childhood is a person who is undergoing a process of rapid development and fundamental for the next life.

Child confidence planting is done gradually in accordance with the stages of child development. One of the causes of the child's lack of confidence is the fear and the belief that he cannot do the job he is assigned to. Children with high selfconfidence tend to be more successful at doing what they 
want. Hence the planting of child's confidence is very important. Among these desirable traits, the child's self-esteem becomes one of the most important foundations to make it happen.

\section{Learning Styles}

Learning styles are key to developing performance in work, at school and in interpersonal situations. When we realize how this self and others absorb and process information, we can make learning and communicating easier with our own style. Learning styles by Dunn and Dunn, [14] "defines learning style as the way individuals begin to concentrate on, process, internalize, and retain new and difficult information. "Opinions about learning styles are also reinforced by writing in research conducted by Yang, et al, [15] Learning styles have been recognized as a model for learning and learning disposition / preferences of students.

Research Gulden, Hulya, and Atiye. [16]; A Study on the Development of the learning styles scale for 5-6 year old children. This article describes the results of the study yielding a comparison of 95 visual learning style outcomes, 91 auditory learning styles and 82 kinesthetic learning styles. From the results of this study can be learning styles there are 3 types namely (1) visual learning style, (2) auditory learning style, (3) kinesthetic learning style. Where each learning style has different characteristics although some research results show the percentage of each learning style owned by the group of children has a slight difference but still there is a difference.

\section{RESEARCH METHOD}

The method used in this research is experiment. With a 2 x 2 × 2 factorial design, where the design can be described as follows

\begin{tabular}{|l|l|l|l|l|}
\hline \multirow{2}{*}{} & \multicolumn{2}{|c|}{ A1 Congklak } & \multicolumn{2}{c|}{ A2 Engklek } \\
\cline { 2 - 5 } & $\begin{array}{c}\text { C1 Visual } \\
\text { Learning } \\
\text { Style }\end{array}$ & $\begin{array}{c}\text { C2 Kinesthetic } \\
\text { Learning Styles }\end{array}$ & $\begin{array}{c}\text { C1 } \\
\text { Visual } \\
\text { Learning } \\
\text { Style }\end{array}$ & $\begin{array}{c}\text { C2 } \\
\text { Kinesthetic } \\
\text { Learning } \\
\text { Styles }\end{array}$ \\
\hline $\begin{array}{l}\text { B1 High } \\
\text { Confident }\end{array}$ & A1B1C1 & A1B1C2 & A2B1C2 & A2B1C2 \\
\hline $\begin{array}{l}\text { B2 Believe in the } \\
\text { Low Self }\end{array}$ & A1B2C2 & A1B2C1 & A2B2C1 & A2B2C2 \\
\hline
\end{tabular}

The instrument used is the observation instrument sheet developed by the researcher, to know the reliability of mathematical logical intelligence with Alpha Cronbach obtained value 0.932 , confidence obtained 0.884 and learning style 0.955 . Normality tested with Liliefors test obtained L count data less than $\mathrm{L}$ tabel so it can be concluded data obtained normal distribution. While testing homogeneity with Test Barlett obtained data X2 count smaller than X2tabel so that from data obtained conclusion have homogeneous variance.
Data analysis was performed with three-way ANOVA at significant level $\alpha=0.05$. If it turns out in hypothesis testing there is interaction then continued with TukeyTest.

\section{RESULT AND DISCUSSION}

TABle of Anava Results 3 Paths

\begin{tabular}{|c|c|c|c|c|c|c|}
\hline \multirow{2}{*}{ SumberVarians } & \multirow{2}{*}{$\mathrm{JK}$} & \multirow{2}{*}{$\mathrm{dk}$} & \multirow{2}{*}{ RJK } & \multirow{2}{*}{$\mathrm{F}_{\text {hitung }}$} & \multicolumn{2}{|c|}{$\mathrm{F}_{\text {tabel }}$} \\
\hline & & & & & 0,05 & 0,05 \\
\hline A & 1 & 260,042 & 260,042 & $21,722^{*}$ & 3,95 & 6,93 \\
\hline B & 1 & 96,000 & 96,000 & $8,019^{*}$ & 3,95 & 6,93 \\
\hline $\mathrm{C}$ & 1 & 266,667 & 266,667 & $22,275^{*}$ & 3,95 & 6,93 \\
\hline $\mathrm{AB}$ & 1 & 1365,042 & 1365,042 & $114,023^{*}$ & 3,95 & 6,93 \\
\hline $\mathrm{AC}$ & 1 & 693,375 & 693,375 & $57,918^{*}$ & 3,95 & 6,93 \\
\hline BC & 1 & 522,667 & 522,667 & $43,659^{*}$ & 3,95 & 6,93 \\
\hline $\mathrm{ABC}$ & 1 & 176,042 & 176,042 & $14,705^{*}$ & 3,95 & 6,93 \\
\hline D & 88 & 1053,500 & 11,972 & & & \\
\hline Total & 95 & 4433,333 & & & & \\
\hline
\end{tabular}

The explanation of the above table is as follows:

1. There are differences in mathematical logical intelligence groups of children who are given traditional games of congklak and traditional games of the complex. This is evidenced by the result of ANAVA calculation of 3 factors at source of variant of group A shows Fhitung $=21,722$ bigger than Ftabel $=3,95$ at at $=0,05$, then $\mathrm{H} 0$ is rejected. The conclusion that can be taken is the traditional game congklak better impact on improving children's logical mathematical intelligence. The results obtained are better in the traditional game of congklak because the game is sharpening the child's reasoning power. Strategy is required in this game so the seeds are not taken off opponent. The process of thinking in managing strategy in the traditional game of congklak will hone the logical intelligence of the child on the concept of logical thinking ability. It is like Gardner,[5] argues that the theory of multiple intelligences, one of which says that many ways children learn and children use different intelligence to learn a skill or concept. One of the skills that is learned by children is the ability to handle numbers, pattern calculations, logical and scientific thinking as part of mathematical logical intelligence characteristics. According to the Gardner,[5] theory concept many factors determine a person in achieving mathematical logical intelligence in addition to talent, the individual process solving a very remarkable problem requires the support of empirical criteria. The concept of Piaget's theory, (in Jasmine) [6] as the basis for the development of intelligence in children is obtained through how children explore what is around them. Related to congklak games have more good impact on mathematical logical intelligence of children when Piaget mathematical logical intelligence results, (in Jasmine,) [6] also asserted that when children do traditional games congklak children 
explore with the environment and also learn their own knowledge. If the child is not given freedom of exploration then the child tends to be passive so it needs to look for activities that can stimulate children more active in increasing the logical intelligence of mathematical children as well as types of games such as traditional games congklak. The view of Piaget is then more profoundly examined as constructivism, that is, children have an active and constructive characteristic, when the child constructs his own knowledge involving the thought of their mental processes there is a logical process of mathematical forming through the process until it finds new knowledge.

2. There is a difference of mathematical logical intelligence groups of children in children who have high confidence and low. This is evidenced by the result of Anava 3 lane counting on the source of group B variant indicating that Fcount $=8,019$ is greater than Ftable $=3.95$ at $\alpha=0.05$, then $\mathrm{HO}$ is rejected. The conclusion that can be drawn is that higher self-esteem has better impact on improving children's logical mathematical intelligence. High selfesteem has a better effect on mathematical logical intelligence. Empirical data show that children who have high confidence obtain a higher score than in children who are low confidence. The results of this study strengthen Hall and Fishburne research, (in Krista, Graig and Graham,) [17] states that self-confidence is very important and a success factor of an athlete in a game, so that if the self-confident is low then the athlete may lose success in achieving his achievement. Similarly, in early childhood confidence requires many factors to be developed because it is very important for the child's life. If the child does not have high self-esteem the child will perform activities with hesitation and not formed a good self-concept. Educators, parents or the community around the child need to do relate learning can increase the belief of children with more so that children grow up according to the stage of his age formed a positive self-concept. Children can improve their abilities if they get good stimulation and guidance from adults according to the stage of growth and development. Child's confidence is a must-have for the child's interests in interacting with others. Similarly, as Skinner points out, [18] when children will become successful in their social life, confidence must be one of the qualities that must be introduced, when the child has a strong self-confidence that other mental development is also positive.

3. There are differences in mathematical logical intelligence groups of children aged 5-6 years in children who have visual and kinesthetic learning styles. This is evidenced by the results of Anava 3 lane counting on the source of the $\mathrm{C}$ group variant indicating that Fcount $=22.275$ is greater than Ftable $=3.95$ at $\alpha=0.05$, then $\mathrm{H} 0$ is rejected. The conclusion that can be drawn is the visual learning style has a better impact on improving children's logical mathematical intelligence. Visual learning styles have a better effect on mathematical logical intelligence. Learning style in this research is as effort of child in receiving, interacting and looking at the surrounding environment so that child is able to absorb all information related to learning process that passes. Each child's learning style is different. Every child with all his unique traits has his own learning style; this difference is at once a hallmark of his personality. The learning style according to Susilowati, [19] has conducted empirical research related to the understanding of early childhood learning styles in which the learning style is key to developing performance, at school and in interpersonal situations. Early children prefer to observe directly, when the direct observation that the sense of vision is functioning properly so it needs to do stimulation with activities that can hone the visual learning style of children with activities that many observations directly to be more meaningful for children. Research by Balat, at.al, [20] range of scales obtained by children aged 5-6 years a total of 270 about learning styles obtained data that 95 visual learning styles, 91 auditory learning styles and 82 kinesthetic learning styles. The results of this study is very important because it contributes to the specification of learning styles.

4. There is an interaction effect between traditional games and self-confidence in mathematical logical intelligence of children aged 5-6 years. From the graph above is known to have a meeting at one point ordinate so intersect and also parallel, although not intersecting the line if continued to meet in ordinate as well.

5. There is an interaction effect between traditional games and learning styles on logical mathematical intelligence of children aged 5-6 years. This is proved by the result of counting of Anava 3 lane on source of AC group variant shows that $\mathrm{F}$ hitung $=57,918$ is bigger than $\mathrm{F}$ tabel $=3,95$ at $\alpha=0,05$, then $\mathrm{H} 0$ is rejected. The conclusion that can be taken is that there is an interaction effect between traditional game and learning style to logical mathematical intelligence of children aged 5-6 years. Thus there is interaction of the traditional game depending on the learning style.

6. There is an interaction effect between confidence and learning styles to logical mathematical intelligence of children aged 5-6 years. This is proved by the result of counting of Anava 3 lane on source of variant of $\mathrm{BC}$ group showing that $\mathrm{F}$ count $=43,659$ bigger than $\mathrm{F}$ tabel $=3,95$ at $\alpha=0,05$, then $\mathrm{H} 0$ is rejected. The conclusion that can be taken is there is influence of interaction between confidence and learning style to logical mathematical intelligence.

7. There is an interaction effect between traditional games, self-confidence and learning styles to logical mathematical intelligence of children aged 5-6 years. This is evidenced by the result of counting of Anava 3 lane on source of variant of group $\mathrm{ABC}$ shows that Fcount $=14,705$ bigger than Ftabel $=3,95$ at $\alpha=0,05$, then $\mathrm{H} 0$ is rejected. The conclusion that can be taken is that there is an interaction effect between traditional game, self-confidence and learning style to logical mathematical intelligence of the child. 
The effect of interaction between $\mathrm{ABC}$ can be seen in the graph below:
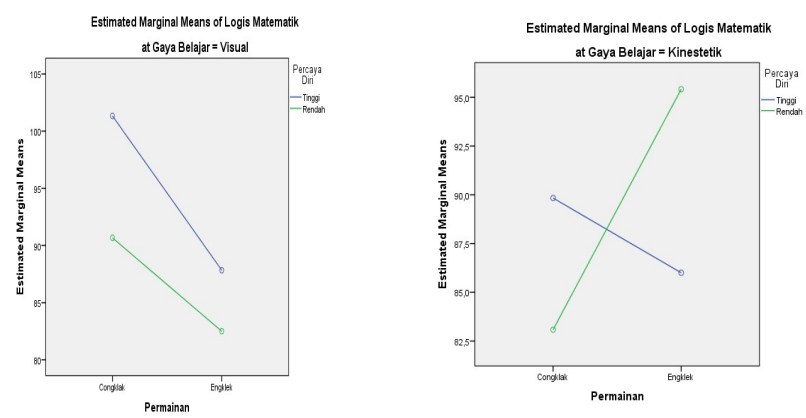

From the graph above is known there is a meeting at one point ordinate so intersect and also parallel, although not intersect the line if continued will meet in ordinate too.

\section{CONCLUSION AND RECOMMENDATION}

Based on the results of hypothesis testing and discussion of research, can put forward the conclusion if want to improve mathematical logical intelligence through the traditional game should pay attention to the level of confidence and learning styles owned by children.

The logical development effort of mathematical intelligence of children using traditional game intervention proved effective use as the concept of early childhood learning using play as a way of learning. To optimize early childhood development, the researchers recommend several things as follows:

1. Government stakeholders should keep supervising and issuing consignment policies related to the implementation of learning in early childhood more emphasis on playing because of the large number of PAUD institutions that are still implementing oriented learning academic achievement only.

2. Early childhood educator as the main role in the field, your child is the investment of the nation who must get the right handling in accordance with the stages of its development. Early childhood learning places the basic foundation of all aspects of child development by playing, if the educator wants the child to master "Calistung" stick to the concept of learning to play children.

3. Elementary School Institution, more cooperate with institute of PAUD organizer to give priority to children with age that have fulfilled the requirement of elementary entrance which become priority not on the concept of "Calistung" mastery only. This is related to the curriculum of early childhood that organizes play conceptual learning as a developmental process of 6 aspects of Moral Religion Value, Social Emotional, Language, Cognitive, Physical Motoric, and Art. The conclusion that can be drawn is that here is an interaction effect between traditional game and confident to the mathematical logical intelligence of children aged 5-6 years. Thus there is a traditional game interaction depends on confidence.

\section{References}

[1] Sujarno, dkk. Pemanfaatan Permainan Tradisional Dalam Pembentukan Karakter Anak. Kementrian Pendidikan dan Kebudayaan. Dirjen Balai Pelestarian Nilai Budaya Yogyakarta. 2013. P.6

[2] Wang, J-C,. Games Unplugged Dolanan anak, Traditional Javanese Children's Singing Games In the 21-st Century General Music Classroom. SAGE Publication. 2014.

[3] Maclellan, E., How Might Teacher Enable Learner Self-Confidence? A Review Study. Educational Rewiew. Vol.66, No.1. 2014.

[4] Rodica. M NICULESCU. Are Competencies And Committed Learning Style Concepts To Be Connected To Early Education? Journal Plus Education, ISSN: 1842-077X, E-ISSN (online) 2068 1151 Vol Special issue.2014.

[5] Gardner, H. Multiple Intelligences, Learning and Mind Series. Handbook. pp.3-4

[6] Jasmine. J. Mengajar Dengan Metode Kecerdasan Majemuk, Bandung: Nuansa, 2007. p19

[7] Suharnan., Psikologi Kognitif., Surabaya; Srikandi, 2005. pp; 157158.

[8] Armstrong. T. Multiple Intelligences. In The Clasroom. ASDC.1994. $\mathrm{p} ; 6$

[9] Ajila, C.O \&Olowu, A.A., Games and Early Childhood In Nigeria: A Critical Focus On Yoruba Traditional Childres Games.University Of Adelaide Libraries. 2014.

[10] Ja'far, A,. Yani, \&Sigit,.Terciptanya Buku Ilustrasi Permainan Tradisional Sebagai Upaya Pelestarian Warisan Budaya Lokal, (Art Nouvean, Vol.3 No.1, 2014)

[11] Apriani, D., Penerapan Permainan Tradisional Engklek Untuk menngkatkan kemampuan Motorik Kasar Anak Kelompok B RA Al Hidayah 2 Tarik Sidoarjo. (Jurnal Unesa. Online) Online; diakses 13 April 2016.

[12] Flowers, J. \& Albert, M. Modification of low self-confidence in elementary school childrens, the journal of educational research. Vol.66 No.1. 1972.

[13] Desmita. Psikologi Perkembangan PesertaDidik. Bandung; Rosda,. 2011.

[14] Dunn, R. Dkk. Impact of learning style instructional strategies on studients achievement and attitudes: perceptions of educators in diverse institutions. Copyright heldref publications. 2008.

[15] Yang, T.-C., Hwang, G.-J., \& Yang, S. J.-H. Development of an adaptive learning system with multiple perspectives based on students' learning styles and cognitive styles. Educational Technology \& Society. ISSN 1436-4522 (online) and 1176-3647 (print). (C) International Forum of Educational Technology \& Society (IFETS). 2013.

[16] Hülya, B. \&Atiye.A.O. A Study on the Development of the Learning Styles Scale for 5-6 Year-Old Children. Elementary Education Online, 11 (2),480-490, 2012.

[17] Krista M.C, Graig H \& Graham F. Playing with confidence: the relationship between imagery use and self-confidence and self efficacy in youth soccer player. Journal of sport sciences. Desember 2008.

[18] Skinner. R. B. The Relationship between Confidence and performance. Throghout a Competitive Season. 2013.

[19] Susilowati, R. Pemahaman Gaya Belajar PadaAnak Usia Dini. Jurusan Tarbiyah STAIN Kudus. Vol.1, No.1 Juli-Desember. 2013.

[20] Balat, . A Study on development of learning styles scale for 5-6 years old children. Elementary education, online. 11 (2). 2012. 